\title{
Exchange Rates and Monetary Policy in Emerging Market Economies*
}

\author{
Michael B. Devereux \\ University of British Columbia and CEPR
}

Philip R. Lane

Trinity College Dublin and CEPR

This draft: June 2001

\begin{abstract}
This paper investigates the effects of exchange rate regimes and alternative monetary policy rules for an emerging market economy that is subject to a volatile external environment in the form of shocks to world interest rates and the terms of trade. In particular, we highlight the impact of financial frictions and the degree of exchange rate pass through in determining the relative performance of alternative regimes in stabilizing the economy in the face of external shocks. Our results are quite sharp. When exchange rate pass-through is high, a policy of non-traded goods inflation targeting does best in stabilizing the economy, and is better in welfare terms. When exchange rate pass-through is low, however, a policy of strict CPI inflation targeting is better. In all cases, a fixed exchange rate is undesirable. In addition, financial frictions have no implications for the ranking of alternative policy rules.
\end{abstract}

Keywords: monetary policy, exchange rates, emerging markets. JEL Codes: E50, F02, F41.

\footnotetext{
* We thank seminar participants at the Hong Kong Institute for Monetary Research, the Bank of England, Universitat Pompeu Fabra and University College London. We are grateful to Mathias Hoffman for research assistance and the Social Science Research Council of the Royal Irish Academy for financial support. This work is part of a research network on 'The Analysis of International Capital Markets: Understanding Europe's Role in the Global Economy', funded by the European Commission under the Research Training Network Programme (Contract No. HPRN-CT-1999-00067). Devereux thanks SSHRC for financial support and Lane also gratefully acknowledges the support of a TCD Berkeley Fellowship.
} 


\section{Section 1. Introduction}

Since the crises of the late 1990s, there has been tremendous interest in the design of appropriate monetary policies for emerging market economies. Should these economies attempt to peg their exchange rates to the US dollar via currency boards or dollarization, or should they allow the exchange rates to float and follow instead a domestically oriented monetary policy geared towards inflation control, similar to the inflation targeting that has been successfully applied in many western economies in the past decade?

This paper develops a simple modelling framework in order to evaluate alternative monetary policy rules for emerging markets, and in particular we ask how important are movements in exchange rate rates for implementing such rules. The model is specialised towards the emerging market environment in two ways. First, the emerging market economy may have specific structural characteristics that make it more vulnerable to external shocks. Two such features are constraints on the financing of investment through external borrowing, and the speed by which exchange rate shocks feed through to the domestic price level. The second way in which the model is geared towards emerging markets is in our measurement of shocks. We calibrate our model with the observed shocks to interest rates and external terms of trade for Asia. The central question addressed is the appropriate monetary policy for an emerging market, given these structural characteristics and the pattern of external shocks.

Much of the literature on emerging market crises has focused on inconsistencies in policy making, and problems of sustainability of monetary and fiscal policy. By contrast, our paper does not investigate the credibility of monetary policies, or the interaction between political constraints and macroeconomic policies. 
Rather, we assume that all monetary policies are equally credible, and simply investigate the properties of alternative rules in terms of economic stabilisation and welfare.

The presence of financial market imperfections in capital inflows to emerging markets has received widespread attention in the last few years. An important theme in this literature is the moral hazard problems with financing investment in emerging markets, where contracts may be less enforceable than in Western economies. Accordingly, we explore the role of collateral constraints in investment financing for emerging markets, following the work of Bernanke, Gertler, and Gilchrist (1999) [hereafter BGG]. In particular, as emphasized by Krugman (1999), Aghion, Bacchetta and Banerjee (2001) and others, emerging market borrowers may find that interest rate and exchange rate fluctuations have large effects on their real net worth position, and so, through balance sheet constraints affecting investment spending, have much more serious macroeconomic consequences than for richer industrial economies. Our interest is in how these features affect the choice of monetary rules. For instance, it is suggested by Eichengreen and Hausmann (1999) and Calvo (1999) that emerging market economies may be much more reluctant to allow freely floating exchange rates due to the problem of 'liability dollarization' in the presence of balance sheet constraints on external borrowing.

A second important feature of emerging markets is the degree to which their price levels are sensitive to fluctuations in exchange rates. As emphasised by Calvo and Reinhart (2001), exchange rate shocks in emerging market economies tend to feed into aggregate inflation at a much faster rate than in industrial economies. While this difference may be due to historical features related to the conduct of monetary policy, 
we simply focus on whether and how this difference affects the choice of monetary policy.

We compare three different types of monetary rules. While a fixed exchange rate is a well-defined rule for a small economy, there is an infinite variety of different types of 'floating' exchange rates. We restrict our attention to two important rules: a policy of CPI inflation targeting, and a policy of targeting inflation in a subset of the CPI consisting of non-traded goods prices. As we will see, the latter is a robust and attractive monetary rule in a wide variety of circumstances.

While we focus on two different types of shocks that hit emerging markets --interest rate shocks and terms of trade shocks --- it turns out that our results regarding optimal monetary rules do not really depend on the source of shocks. In addition, echoing Cespedes, Chang and Velasco (2001a, 2001b) and Gertler, Gilchrist and Natalucci (2001) in quite different settings, we find that external financing constraints have no implications for the ranking of monetary rules. ${ }^{1}$ While balance sheet constraints in the presence of liability dollarisation is an important propagation channel, it essentially generates a magnification effect in response to all shocks, without altering the ranking of alternative monetary policy rules in welfare terms.

Our results show that, in the presence of high exchange rate pass through, the best policy for an emerging market economy is to strictly target inflation in nontraded goods prices alone. This tends to stabilise output in response to external shocks and also maximises welfare, when compared to the alternative rules. Either an exchange rate peg or a policy of strict CPI inflation targeting, by contrast, destabilises output, and is welfare inferior. Nevertheless, there is an element of trade-off involved in using a non-traded goods price inflation target. The output stabilisation can be 
achieved only by very high volatility in the nominal and real exchange rate, and consequently, high inflation volatility. If a policy maker were more concerned with inflation than our representative individual welfare index suggests she should be (perhaps for reasons of credibility along the lines of Rogoff 1985), then this might reduce the attractiveness of the non-traded goods price inflation targeting rule.

When exchange rate pass-through is low however, we find that the monetary policy choice is altered considerably. While an exchange rate peg is still quite undesirable, a policy of CPI inflation targeting is now much more attractive in this situation. The reason is that the policy maker can simultaneously target inflation strictly, but still allow high nominal exchange rate volatility in order to stabilise the real economy in face of external shocks. The low rate of pass through ensures that exchange rate shocks do not destabilise the price level. When pass through is very low, the exchange rate no longer acts as an 'expenditure-switching' device, altering the relative price of home and foreign goods, but is still of critical importance in stabilising demand by cushioning the effective real interest rate faced by consumers and firms in the emerging market.

The important feature of low pass through is that it eliminates the trade-off between output volatility and inflation volatility in the open economy. For instance, a policy of non-traded goods inflation targeting does better than a pegged exchange rate on both counts; output volatility and inflation volatility under this rule are lower than they are under a pegged exchange rate.

\footnotetext{
${ }^{1}$ The former set of authors derive some analytical results in a highly-stylised stripped-down model. The latter is closer to this paper in building a quantitative model. However, neither allow for nontradables or incomplete pass through or consider the same set of monetary policy rules.
} 
Lowering the rate of pass through also alters the welfare rankings of alternative rules. ${ }^{2}$ With rapid pass-through, the non-traded goods inflation targeting rule is welfare dominant, with or without external financing constraints. But with delayed pass through the CPI inflation targeting rule is preferable. Intuitively, the CPI rule does a better job of stabilising both sectors in the presence of nominal sluggishness in both the non-traded and traded goods sector. These results suggest that a low rate of exchange rate pass-through may be an important prerequisite for the success of inflation targeting in emerging markets.

The paper is organised as follows. Section 2 sets out the model. Section 3 discusses calibration and the solution of the model. Section 4 develops the main results. Some conclusions follow.

\section{Section 2. Monetary Policy in a Small Open Economy}

\section{Outline of the model}

The structure is a standard two-sector 'dependent economy' model. Two goods are produced: a domestic non-traded good, and an export good, the price of which is fixed on world markets.

Four central aspects of the model are a) the existence of nominal rigidities; b) the requirement that all foreign liabilities be denominated in foreign currency; c) the presence of lending constraints on investment financing; and d), the degree of exchange rate pass through in import prices.

The first feature is of course necessary to motivate a role for the exchange rate regime at all. The specific assumption made is that the prices of non-traded goods are set by individual firms, and adjust only over time. The specification of price setting follows Calvo (1983) and Yun (1996).

\footnotetext{
${ }^{2}$ Monacelli (1999) also examines the implications of low pass through for alternative monetary policy
} 
The second feature of the model is based on the observation by Eichengreen and Hausmann (1999), among others, that emerging market economies have little ability to issue external debt denominated in local currency. They also note that almost all the external debt issued by East Asian countries during the period of rapid inflows in the early 1990s was denominated in US dollars.

With respect to the borrowing constraint on investment, we follow the BGG model, which assumes that entrepreneurs undertake investment projects with returns that can be observed by lenders only at a cost. This leads entrepreneurs to face higher costs of external financing of investment relative to internal financing, and as a result investment depends on entrepreneurial net worth.

Finally, it is well established from Engel (1999) that deviations from the law of one price are a major factor in determining real exchange rates. Accordingly, we consider alternative speeds of adjustment of import prices to exchange rate movements.

There are four sets of domestic actors in the model: consumers, production firms, entrepreneurs, and the monetary authority. In addition, there is a 'rest of world' sector where foreign-currency prices of export and import goods are set, and where lending rates are determined. ${ }^{3}$

\section{Consumers}

We assume that the economy is populated by a continuum of consumer/households of measure unity. We will describe the model in terms of the representative consumer. She has preferences given by

$$
U=E_{0} \sum_{t=0}^{\infty} \beta^{t} u\left(C_{t}, H_{t}, \frac{M_{t}}{P_{t}}\right)
$$

rules but his model only contains tradables and there are no financial frictions. 
where $C_{t}$ is a composite consumption index, $H_{t}$ is labor supply, and $\frac{M_{t}}{P_{t}}$ represents real balances, with $M_{t}$ being nominal money balances, and $P_{t}$ being the consumer price index. Let the functional form of $u$ be given by $u=\frac{1}{1-\sigma} C^{1-\sigma}+\frac{\chi}{1-\varepsilon}\left(\frac{M_{t}}{P_{t}}\right)^{1-\varepsilon}-\eta \frac{H_{t}^{1+\psi}}{1+\psi}$

Composite consumption is a CES function of consumption of non-traded goods and an import good, where $C_{t}=\left(a^{1 / \rho} C_{N t}^{1-1 / \rho}+(1-a)^{1 / \rho} C_{M t}^{1-1 / \rho}\right)^{\frac{\rho}{\rho-1}}, \rho>0$. The implied consumer price index is then $P=\left(a P_{N t}^{1-\rho}+(1-a) P_{M t}^{1-\rho}\right)^{\frac{1}{1-\rho}}$. Since we wish to introduce nominal price setting in the non-traded goods sector, we need to allow for imperfect competition in that sector. In order to do this, we assume that the consumption of non-tradable goods is differentiated as follows:

$$
C_{N t}=\left(\int_{0}^{1} C_{N t}(i)^{1-\lambda} d i\right)^{1 /(1-\lambda)},
$$

where $\lambda>1$.

We assume that consumers do not face any capital market imperfections. Therefore, the consumer can borrow directly in terms of foreign currency at a given interest rate $i_{t}^{*}$. The assumption of a frictionless consumer credit market is an extreme one. But the critical aspect of the financial frictions in the model below revolves around their impact on investment financing. Thus, the results of the model with respect to the properties of alternative monetary policies would be essentially unaffected by the presence of credit constraints at the consumer level.

\footnotetext{
${ }^{3}$ Since our focus is on emerging market economies that are plausibly price-takers on world markets, we assume that the foreign-currency prices of exports and imports are exogenously determined.
} 
A consumer's revenue flow in any period comes from her supply of hours of work to firms for wages $W_{t}$, transfers $T_{t}$ from government, profits from firms in the non traded sector (see below) $\Pi_{t}$, domestic money $M_{t}$, less her debt repayment from last period $\left(1+i_{t}^{*}\right) S_{t} D_{t}$, where $S_{t}$ is the nominal exchange rate and $D_{t}$ is the outstanding amount of foreign-currency debt. ${ }^{4}$

She then obtains new loans from the international capital market, and uses these to consume and acquire new money balances. Her budget constraint is thus

$$
P_{t} C_{t}=W_{t} L_{t}+\Pi_{t}+S_{t} D_{t+1}+M_{t}-M_{t-1}-\left(1+i_{t}^{*}\right) S_{t} D_{t}+T_{t}
$$

The household will choose non-traded and traded goods to minimize expenditure conditional on total composite demand $C_{t}$. Demand for non-traded and imported goods is then

$$
C_{N t}=a\left(\frac{P_{N t}}{P_{t}}\right)^{-\rho} C_{t} \quad C_{M t}=(1-a)\left(\frac{P_{M t}}{P_{t}}\right)^{-\rho} C_{t}
$$

The consumer optimum can be characterized by the following conditions.

$$
\begin{aligned}
& \frac{1}{\left(1+i_{t+1}^{*}\right)} C_{t}^{-\sigma}=E_{t} \beta \frac{S_{t+1}}{S_{t}} \frac{P_{t}}{P_{t+1}} C_{t+1}^{-\sigma} \\
& \frac{W_{t}}{P_{t}}=\eta C_{t}^{\sigma} H_{t}^{\psi} \\
& \left(\frac{M_{t}}{P_{t}}\right)^{-\varepsilon}=\chi C_{t}^{-\sigma}\left(1-E_{t} d_{t+1}^{h}\right)
\end{aligned}
$$

Equation (3) represents the Euler equation for optimal consumption. Equation (4) is the labour supply equation, while equation (5) gives the implicit money demand function. Money demand depends on domestic nominal interest rates. The domestic nominal discount factor is defined as

\footnotetext{
${ }^{4}$ Note that consumers do not receive any capital income, as all investment in this economy is done by
} 
(6) $d_{t+1}^{h} \equiv \frac{1}{1+i_{t+1}} \equiv \beta \frac{C_{t+1}^{-\sigma}}{C_{t}^{-\sigma}} \frac{P_{t}}{P_{t+1}}$

where $i_{t+1}$ is the domestic nominal interest rate. The combination of (3) and (6) gives the representation of uncovered interest rate parity for this model.

\section{Production Firms}

Production is carried out by firms in each sector. Sectors differ in their production technologies. Both types of goods are produced by combining labour and capital. Following BGG (1999), labour comes from both consumer/households and from entrepreneurs. Thus, in the non-traded sector, effective labour of firm $i$ is defined as $L_{N i t}=H_{N i t}^{\Omega} H_{N i t}^{e(1-\Omega)}$, where $H_{N i t}$ is employment of household labour and $H_{N i t}^{e}$ is employment of entrepreneurial labour. The overall production technology for a firm in the non-traded goods sector is then

$$
Y_{N i t}=A_{N} K_{N i t}^{\alpha} L_{N i t}^{1-\alpha},
$$

where $A_{N}$ is a productivity parameter.

Similarly, exporters (all domestically-produced tradables are exported) use the production function

$$
Y_{X t}=A_{X} K_{X t}^{\gamma} L_{X t}^{1-\gamma}
$$

Firms in each sector hire labour and capital from consumers and entrepreneurs, and sell their output to consumers, entrepreneurs (for their consumption) and capital producing firms. Cost minimizing behaviour then implies the following equations

$$
W_{t}=M C_{N t}(1-\alpha) \Omega \frac{Y_{N i t}}{H_{N i t}}
$$




$$
W_{N t}^{e}=M C_{N t}(1-\alpha)(1-\Omega) \frac{Y_{N i t}}{H_{N i t}^{e}}
$$

$$
\begin{aligned}
& R_{N t}=M C_{N t} \alpha \frac{Y_{N i t}}{K_{N t}} \\
& W_{t}=P_{X t}(1-\gamma) \Omega \frac{Y_{X t}}{H_{X t}} \\
& W_{X t}^{e}=P_{X t}(1-\gamma)(1-\Omega) \frac{Y_{X t}}{H_{X t}^{e}}
\end{aligned}
$$

$$
R_{X t}=P_{X t} \gamma \frac{Y_{X t}}{K_{X t}}
$$

where $M C_{N t}$ denotes the marginal production cost for a firm in the non-traded sector (which is common across firms). Equations (9), (10), (12) and (13) describe the optimal employment choice for firms in each sector.

It is assumed that entrepreneurial labour supply to each sector is inelastic in supply and fixed across sectors. Thus, the entrepreneurial wage differs across sectors. Equations (11) and (14) describe the optimal choice of capital. Note that the price of the traded export good is $P_{X t}$. Movements in this price, relative to the import price $P_{M t}$, represent terms of trade fluctuations for the small economy.

Production of capital goods is also carried out by competitive firms. These firms combine imports and non-traded goods to produce unfinished capital goods. There are adjustment costs of investment, so that the marginal return to investment in terms of capital goods is declining in the amount of investment undertaken, relative to the current capital stock.

Capital stocks in the export and non-traded sectors evolve according to

$$
K_{X t+1}=\phi\left(\frac{I_{X t}}{K_{X t}}\right) K_{X t}+(1-\delta) K_{X t}
$$




$$
K_{N t+1}=\phi\left(\frac{I_{N t}}{K_{N t}}\right) K_{N t}+(1-\delta) K_{N t}
$$

where the function $\phi$ satisfies $\phi^{\prime}>0$, and $\phi^{\prime \prime}<0$. This reflects the presence of adjustment costs of investment.

Investment in new capital requires imports and non-traded goods in the same mix as the household's consumption basket. Thus, the price of a unit of investment, in either sector, is $P_{t}$, the price of one unit of the consumption index. Competitive capital producing firms will then ensure that the price of capital sold to entrepreneurs is

$$
Q_{X t}=\frac{1}{\phi^{\prime}\left(\frac{I_{X t}}{K_{X t}}\right)} P_{t}
$$

$$
Q_{N t}=\frac{1}{\phi^{\prime}\left(\frac{I_{N t}}{K_{N t}}\right)} P_{t}
$$

\section{Price setting}

Firms in the non-traded sector set prices in advance. Following the method of Calvo (1983) and Yun (1996), assume that firms face a probability $(1-\kappa)$ in every period of altering their price, independent of how long their price has been fixed. Following standard aggregation results, the non-traded goods price follows the partial adjustment rule

$$
P_{N t}^{1-\lambda}=(1-\kappa) \tilde{P}_{N t}^{1-\lambda}+\kappa P_{N t-1}^{1-\lambda}
$$

where $\tilde{P}_{N t}$ represents the newly set price for a firm that does adjust its price at time $t$. The evolution of $\widetilde{P}_{N t}$ is then governed by

$$
\tilde{P}_{N t}=(1-\beta \kappa) M C_{N t}+\beta \kappa E_{t} \tilde{P}_{N t+1} .
$$


Taking a linear approximation of (19) and (20), assuming an initial steady state where the rate of change of $P_{N t}$ is constant, we can derive the familiar forward-looking inflation equation:

$$
\pi_{N t}=\lambda m c n_{t}+E_{t} \pi_{N t+1}
$$

where $m c n_{t}$ represents the log deviation of real marginal cost in the non-traded sector, $M C_{N t} / P_{N t}$ from its steady state level (of unity). Equation (21) is analogous to the forward-looking inflation equation in Clarida, Gali and Gertler (1999). The key difference here is that both marginal costs and inflation are specific to the nontradable sector.

\section{Local Currency Pricing}

We assume that the law of one price must hold for export goods, so that

$$
P_{X t}=S_{t} P_{X t}^{*}
$$

For import goods however, we allow for the possibility that there is some delay between movements in the exchange rate and the adjustment of imported goods prices. Without loss of generality, we may assume that imported goods prices are adjusted in the same manner as prices in the non-traded sector. That is, a measure $1-\kappa^{*}$ of foreign firms adjust their prices in every period. Thus, the imported good price index for domestic consumers moves as

$$
P_{M t}^{1-\lambda}=\left(1-\kappa^{*}\right) \tilde{P}_{M t}^{1-\lambda}+\kappa^{*} P_{M t-1}^{1-\lambda}
$$

where $\tilde{P}_{M t}$ represents the newly set price for a foreign firm that does adjust its price at time $t$.

The evolution of $\tilde{P}_{M t}$ is then governed by

$$
\tilde{P}_{M t}=\left(1-\beta \kappa^{*}\right) S_{t} P_{M t}^{*}+E_{t} \beta \kappa^{*} \tilde{P}_{M t+1} .
$$


The interpretation of (24) is that the foreign firm wishes to achieve an identical price in the home market as in the world market. But it may incur a lag in adjusting its price. The coefficient $\kappa^{*}$ determines the delay in the 'pass-through' of exchange rates to prices in the domestic market. Using the same approach as with equations (20) and (21), we can derive the familiar inflation equation:

$$
\pi_{M t}=\lambda\left(\hat{s}_{t}+\hat{p}_{m t}^{*}-\hat{p}_{m t}\right)+E_{t} \pi_{M t+1}
$$

where $\pi_{M t}$ is the domestic-currency inflation rate for the imported good, and $\hat{s}_{t}$ and $\hat{p}_{m t}^{*}$ represent the log deviation of the exchange rate and the world price for the import good from steady state.

\section{Entrepreneurs}

Unfinished capital is transformed by entrepreneurs and sold to the final goods sector. Following BGG, the broad notion is that capital producers face idiosyncratic risk arising from unverifiable individual investment outcomes. The effective result of this is to make borrowing more costly for entrepreneurs than financing investment out of internal resources. In borrowing from capital markets, entrepreneurs face an external risk premium. Here we incorporate a simplified version of the BGG set-up which, in the aggregate, preserves the essential features of the credit channel effects for investment dynamics.

There are two groups of entrepreneurs. One group provides capital to the non-traded sector, while the other provides capital to the traded sector. ${ }^{5}$

Entrepreneurs must borrow in foreign currency. We set this as a constraint on the types of borrowing contracts rather than deriving it endogenously. An

\footnotetext{
${ }^{5}$ Since capital is quasi-specific to each sector, separating the provision of capital to the different sectors is the simplest way to handle the entrepreneurial capital supply decision.
} 
entrepreneur $j$ in the non-traded sector who wishes to invest $K_{N t+1}^{j}$ units of capital must pay nominal price $K_{N t+1}^{j} Q_{t}$. Say that the entrepreneur begins with nominal net worth given by $Z_{N t+1}^{j}$. Then she must borrow in foreign currency an amount given by

$$
D_{N t+1}^{e j}=\frac{1}{S_{t}}\left(K_{N t+1}^{j} Q_{t}-Z_{N t+1}^{j}\right)
$$

The fact that an entrepreneur faces a cost of external capital that is inversely related to her net worth is captured by the assumption that, when borrowing, an entrepreneur in either sector is faced with a risk premium given by $\Psi(z)$, where $z$ is the ratio of net worth to the value of capital. We assume that where $\Psi(1)=1$, and $\Psi^{\prime}()<$.0 . Thus, a higher net worth reduces the external finance risk premium.

The cost of investment funds for an entrepreneur is increasing the amount borrowed. If net worth is large enough so that there is no requirement to borrow, then the cost of borrowed funds equals the world opportunity cost $\left(1+i_{t+1}^{*}\right)$. But the larger is the amount borrowed relative to net worth, the higher the probability of default, and the higher is the cost of funds. By this mechanism, a shock to net worth, generated say by a nominal exchange rate depreciation, may directly reduce investment by increasing the cost of capital.

A risk-neutral entrepreneur that faces such a risk premium will choose a rate of investment such that the expected return, evaluated in terms of foreign currency, equals the cost of capital. Thus, for the non-traded sector, we have

$$
E_{t}\left(R_{K N t+1}^{j} \frac{S_{t}}{S_{t+1}}\right)=\Psi\left(\frac{Z_{N t+1}^{j}}{K_{N t+1}^{j} Q_{t}}\right)\left(1+i_{t+1}^{*}\right) .
$$

At the beginning of each period, an entrepreneur in the non-traded sector receives the amount given by 


$$
R_{K N t}^{j} Q_{t-1} K_{N t}-\left(1+i_{t}^{*}\right) \Psi\left(\frac{Z_{N t}^{j}}{Q_{t-1} K_{N t}^{j}}\right) S_{t} D_{N t}
$$

This represents the nominal return on capital purchased last period, less the interest costs on debt incurred last period, evaluated at the current exchange rate.

The entrepreneurs are assumed to die at any time period with probability $(1-\vartheta)$. They consume only in the period in which they die. Thus, at any given period, a fraction $(1-\vartheta)$ of entrepreneurial wealth is consumed. It is shown in BGG that the functional forms used here allow for aggregation, so that the mean capital stock in each sector is determined by equation (27) as a function of the mean ratio of net worth to the value of capital in that sector. Furthermore, the mean value of net worth of entrepreneurs in the non-traded sector evolves as

$$
Z_{N t+1}=\vartheta\left(R_{K N t} Q_{t-1} K_{N t}-\left(1+i_{t}^{*}\right) \Psi\left(z_{t}\right) S_{t} D_{N t}\right)+W_{N t}^{e}
$$

For an entrepreneur in the non-traded sector, net worth is determined by the unconsumed returns to investment plus the wages earned working in the non-traded sector. Note that net worth depends negatively on the current exchange rate.

The details of the contract structure and net worth dynamics in the export sector are described in the identical way.

Finally, we may define the return to capital to entrepreneurs as depending on both the price of capital and the rental rate offered by firms. Thus

$$
\begin{gathered}
R_{K N t+1}=\frac{R_{N t+1}+(1-\delta) Q_{N t+1}}{Q_{N t}} \\
R_{K X t+1}=\frac{R_{X t+1}+(1-\delta) Q_{X t+1}}{Q_{X t}}
\end{gathered}
$$

\section{Monetary Policy Rules}

Assume that the monetary authority uses a short-term interest rate as the monetary instrument. Given the interest rate, the money supply will be determined 
endogenously by equation (5), the aggregate demand for money arising from the consumer sector. It is important however that interest rate rules are set so as to ensure a unique price level and exchange rate, and to avoid the issue of 'real indeterminacy' that can arise under some interest rate rules in sticky price models. ${ }^{6}$ Under all calibrations of the model, as discussed below, a unique equilibrium is obtained.

The general form of the interest rate rule used may be written as

$$
\left(1+i_{t+1}\right)=\left(\frac{P_{N t}}{P_{N t-1}} \frac{1}{1+\bar{\pi}_{n}}\right)^{\mu_{\pi_{n}}}\left(\frac{P_{t}}{P_{t-1}} \frac{1}{1+\bar{\pi}}\right)^{\mu_{\pi}}\left(\frac{S_{t}}{\bar{S}}\right)^{\mu_{s}}(1+\bar{i})
$$

where it is assumed that $\mu_{\pi_{n}} \geq 0, \mu_{\pi} \geq 0, \mu_{y} \geq 0, \mu_{s} \geq 0$. The parameter $\mu_{\pi_{n}}$ allows the monetary authority to control the inflation rate in the non-traded goods sector around a target rate of $\bar{\pi}_{n}{ }^{7}$. The parameter $\mu_{\pi}$ governs the degree to which the CPI inflation rate is targeted around the desired target of $\bar{\pi}$. Finally, $\mu_{s}$ controls the degree to which interest rates attempt to control variations in the exchange rate, around a target level of $\bar{S}$.

\section{Equilibrium}

In each period, the non-traded goods market must clear. Thus, we have

$$
Y_{N t}=a\left(\frac{P_{N t}}{P_{t}}\right)^{-\rho}\left(C_{t}+I_{N t}+I_{T t}+C_{t}^{N e}+C_{t}^{T e}\right)
$$

Equation (32) indicates that demand for non-traded goods comes from household consumption, investment and the consumption of entrepreneurs. In the calibration of

\footnotetext{
${ }^{6}$ See Woodford (1999) for conditions on interest rate rules required for uniqueness in the price level. In addition, see Clarida, Gali, and Gertler (1999).

${ }^{7}$ When pass-through is full, a target of $\bar{\pi}_{n}=0$ will actually replicate the response of the economy without nominal rigidities of any kind.
} 
the model, the last category is assumed to be very small relative to the size of the economy.

The evolution of the household sector's net debt is given by

$$
S_{t} D_{t+1}=\left(1+i_{t}^{*}\right) S_{t} D_{t}+P_{t} C_{t}-W_{t} L_{t}-P_{N t} Y_{N t}\left(1-\frac{M C_{N t}}{P_{N t}}\right)
$$

The expression on the far right hand side gives the value of profits in the non-traded good sector that is earned by the households' ownership of monopolistic competitive firms. We may add this to the budget constraint of entrepreneurs to obtain the current account equation for the overall economy as

$$
\begin{aligned}
& S_{t} D_{t+1}^{A}-S_{t} D_{t}^{A}=i_{t}^{*} S_{t} D_{t}^{A}-P_{X t} Y_{X t} \\
& +(1-a)\left(\frac{P_{M t}}{P_{t}}\right)^{-\rho}\left(C_{t}+I_{N t}+I_{T t}+C_{t}^{N e}+C_{t}^{T e}\right)
\end{aligned}
$$

Labour market clearing for the household sector implies

$$
H_{N t}+H_{X t}=H_{t}
$$

Finally, the price of the non-traded good and the import good may be recovered from the equations

(35) $P_{N t}=\left(1+\pi_{N t}\right) P_{N t-1}$

(36) $P_{M t}=\left(1+\pi_{M t}\right) P_{M t-1}$ 


\section{Section 3. Solution and Calibration}

We now derive a solution for the model, by first calibrating and then simulating using standard linear approximation techniques. The calibration of the model is somewhat more involved than the usual 'dynamic general equilibrium' framework, since the model has two production sectors and it involves parameters describing the entrepreneurial sector.

The benchmark parameter choices for the model are described in Table 1. Some standard parameter values are those governing preferences. It is assumed that the intertemporal elasticity of substitution in both consumption and real balances is 0.25 . The consumption intertemporal elasticity is within the range of the literature, and the equality between the two elasticities ensures that the consumption elasticity of money demand equals unity, as estimated by Mankiw and Summers (1986). The elasticity of substitution between non-traded and imported goods in consumption is an important parameter, on which there is little direct evidence. Following Stockman and Tesar (1995), we set this to unity. The elasticity of labour supply is also set to unity, following Christiano, Eichenbaum, and Evans (1997). In addition, the elasticity of substitution between varieties of traded goods determines the average price-cost markup in the non-traded sector. We follow standard estimates from the literature in setting a 10 percent mark-up, so that $\lambda=11$.

Assuming that the small economy starts out in a steady state with zero consumption growth, the world interest rate must equal the rate of time preference. We set the world interest rate equal to 6 percent annually, an approximate number used in the macro-RBC literature, so that at the quarterly level, this implies a value of 0.985 for the discount factor $\beta$. 
The factor intensity parameters are quite important in determining the dynamics of the model. In the short run, only labour is mobile between sectors, so the impact of interest rate and terms of trade shocks on output will depend on the labour intensity of the different sectors. For two Asian economies, Malaysia and Thailand, we found that there is clear evidence that the non-traded sector is more labour intensive than the traded sector ${ }^{8}$. Both countries estimates of sectoral wage shares are quite similar. Following these estimates, we set total share of labour in GDP to 52 percent, the labour share of traded goods (i.e. export) output to 30 percent, and the share of wages in non-traded output to 70 percent.

In combination with the other parameters of the model, the parameter $a$, governing the share of non-traded goods in the CPI, determines the share of nontraded goods in GDP. Following the classification followed by De Gregorio et al. (1994), we found that the average share of non-traded goods in total GDP in Thailand was 54 percent over the period 1980-1998. ${ }^{9}$ Cook and Devereux (2001) find a similar figure for Malaysia. Given the other parameters, a value of $a$ equal to 0.55 produces this share.

To determine the degree of nominal rigidity in the model, the value $\kappa$, governing the speed of price adjustment in non-traded goods, must be chosen. Again, in the absence of direct evidence on this, we follow the literature (e.g. Chari, Kehoe and McGratten 1998), and set $\kappa=0.75$, so that prices completely adjust after approximately four quarters. Likewise, with no direct evidence on the speed of adjustment in capital, we follow BGG in setting the $\phi$ function such that the elasticity of Tobin's q with respect to the investment capital ratio is 0.3 .

\footnotetext{
${ }^{8}$ For Malaysia, evidence is presented in Cook and Devereux (2001). For Thailand, an earlier draft of this paper provides estimates: see Devereux and Lane (2000).
} 
We consider two values for the import pass-through coefficient: $\kappa^{*}=0$ and $\kappa^{*}=\kappa$. The former represents the complete pass-through case; the latter implies the same degree of price stickiness in non-traded and traded sectors.

Finally, we choose a steady state risk spread of 200 basis points, as in BGG, and an elasticity of the external finance premium with respect to the net worth to capital ratio equal to 0.025 , and a savings rate of entrepreneurs of 0.9 .

\section{Shocks}

We consider two types of external shock: a) shocks to the world interest rate, and b) terms of trade shocks. In the model, a) is represented by shocks to $i_{t+1}^{*}$, and b) is represented by shocks to $P_{X t}^{*} / P_{M t}^{*}$.

\section{Section 4: External shocks under alternative monetary rules}

Figures 1-6 illustrate the impact of shocks to the countries borrowing rate and shocks to the terms of trade, under the three alternative monetary rules. In order to illustrate the workings of the model, at this stage, we simply assume that each shock is an $\operatorname{AR}(1)$ process with persistence 0.5 . The Figures show alternatively how the collateral constraints and the speed of exchange rate pass-through affects the transmission of shocks to the economy.

\section{Interest Rate Shocks}

Figures 1-3 illustrate the effect of a persistent shock to the world interest rate. Figures 1 and 2 show the impact of the shock without and with the presence of financing constraints respectively, under complete pass-through in import prices.

\footnotetext{
${ }^{9}$ Traded goods were defined as Agriculture, Mining and Quarrying, and Manufacturing. Non-traded goods were Electricity Gas and Water, Construction, Hotel and Retail Trade, Transport Storage and Communications, Education, and other service sectors.
} 
The unanticipated rise in the cost of external borrowing leads first to a fall in total absorption; both private consumption and investment fall. The fall in absorption causes a fall in demand for non-traded goods, leading to a real depreciation. Nontraded goods output falls, while output in the export sector will rise, and the economy experiences a sharp increase in the trade surplus. In principle, the impact of the interest rate spike on output is ambiguous, since total output combines both nontraded goods output and export sector output. As Figure 1 shows, the output impact of the interest rate shock depends sharply on the monetary rule. The non-traded inflation targeting rule rule involves an expansionary monetary policy, since the fall in demand tends to generate a deflation in the non-traded goods sector, so that in order to prevent non-traded goods prices from falling, monetary policy must be expansionary. The monetary expansion in effect stabilises aggregate output. Figure 1 shows that employment actually expands ${ }^{10}$. Note also however that the non-traded inflation targeting rule requires a very large nominal exchange rate depreciation, followed by an appreciation. Due to instantaneous exchange rate pass-through, this means a large initial burst of inflation. The mechanism by which this stabilises GDP is seen in Figure 1. The sharp, but temporary rise in the nominal exchange rate leads to cushioning of the nominal and real interest rate from the full effects of the rise in foreign borrowing. The domestic real interest rate rises by only about half of the rise in the foreign interest rate. This cushions the impact of the shock on absorption, demand, and aggregate GDP.

Under the other two policy rules, however, the interest rate shock tends to be sharply contractionary. Moreover, the exchange rate peg and the inflation target have almost identical implications; to all intents and purposes they become the same policy

\footnotetext{
${ }^{10}$ Remember that the non-traded sector is labour intensive, so an expansion in overall employment is
} 
rule in this case. Both rules must act so as to prevent a nominal exchange rate depreciation, and prevent any increase in aggregate inflation. While the non-traded inflation target rule is expansionary, the exchange rate peg and the inflation targeting rule have a contractionary stance, because the interest rate shock generates pressure for a nominal depreciation and a jump in CPI inflation. By stabilising the nominal exchange rate and inflation, the two rules ensure that the full impact of the foreign real interest rate shock is passed through to the domestic economy, and there is a much larger fall in absorption, output in the non-traded sector, and overall GDP. Now we see that total employment falls. On the other hand, the trade surplus is larger, because total absorption is less.

These results indicate that a foreign interest rate shock is cushioned much more effectively by a non-traded inflation targeting rule than a policy of strict inflation targeting or a pegged exchange rate. How do the presence of collateral constraints in investment affect this conclusion? Figure 2 illustrates the impact of the same foreign interest rate shock when investment in each sector is subject to financing constraints, and external debt is foreign-currency denominated. The key effect of the financing constraints is to increase the downward shift of investment, and so overall absorption, to the interest rate shock. This occurs because the higher borrowing costs reduce the value of existing capital for entrepreneurs in each sector, and also because the unanticipated real exchange rate depreciation raises the debt burden for entrepreneurs. Both channels reduce net worth, raising the effective cost of borrowing, and reducing investment by more than we see in the model without financing constraints.

not inconsistent with aggregate GDP falling slightly. 
In the aggregate, the impact of the financing constraints is therefore to is to magnify the impact of the interest rate shock; output and employment fall by more, and the trade balance increases by more, as the greater fall in absorption causes a sharper collapse in non-traded output.

How do the different monetary policy stances affect the response of the economy to an interest rate shock in the presence of financing constraints? From the figures, the answer clearly is that financing constraints have little or no affect on the policy choice problem. The non-traded inflation targeting rule still acts so as to cushion output from the interest shock, although output falls by more than without the financing constraints. Nevertheless, the ranking of alternative policies remains the same as in the economy without financing constraints.

A second feature of the results with financing constraints is that the response of prices is essentially the same, for each type of policy rule. The rise in the real interest rate, and the real exchange rate deprecation, is essentially identical to the case without the constraints.

We conclude from this that the presence of collateral constraints in external investment for an emerging market economy has essentially no implications for the choice of monetary policy. As we will confirm below, from a welfare perspective, the non-traded inflation targeting rule is still superior to either a nominal exchange rate peg or a strict inflation target. ${ }^{11}$

The results so far are based on the assumption that exchange rate pass-through to imported goods prices is immediate. How does the presence of delayed passthrough, following the specification set out in section 2 above, affect the results?

\footnotetext{
${ }^{11}$ The results remain unchanged when we allow for the possibility that external debt is denominated in domestic currency. When entrepreneurs borrow in domestic currency, one of the channels by which an interest rate shock impacts on net worth (through the unanticipated real exchange rate depreciation
} 
Figure 3 illustrates the response of the economy to an interest rate shock under delayed pass-through ${ }^{12}$. It is important to note that the response under the exchange rate peg is the same as before. When the exchange rate is pegged, the speed of import price response to exchange rate shocks is obviously irrelevant.

From a qualitative point of view, the slower exchange rate pass-through does not change the way in which the emerging market economy responds to shocks. It is still the case that absorption falls, the trade balance improves as resources are shifted into the export good sector, aggregate output falls, and there is a real exchange rate depreciation. This indicates that closing off the 'expenditure-switching' effect, by which exchange rate changes immediately affect the relative price of home to foreign goods, does not alter the qualitative dynamics of the economy.

Quantitatively, however, the presence of delayed pass-through has very significant affects on the response to an interest rate shock. Moreover, it has dramatic implications for the comparison of alternative monetary policy rules. The most significant feature of Figure 3, when compared with Figure 1, is that there is now a very distinct difference between the performance of a strict inflation targeting rule and a pegged exchange rate. When pass-through is instantaneous, a policy maker cannot really stabilise CPI inflation without stabilising the exchange rate. But with delayed pass-through, this is quite possible. Under the strict inflation targeting rule, there is a big initial depreciation in the nominal exchange rate, far larger than the exchange rate response when the inflation targeting rule is applied under full pass-through. The result is that there is a substantial real depreciation under inflation targeting. But a big real depreciation, by generating a large expected appreciation, allows the policy-

raising the real debt burden) is removed. But since the overall net worth effects do not affect the choice of monetary policy, removing this channel cannot alter the results.

${ }^{12}$ In this figure it is assumed that the collateral constraints on investment financing are absent. The case with financing constraints has very similar results. 
maker to cushion the impact of the shock on the real interest rate. As a result, the fall in total absorption and GDP, and the rise in the trade balance is much less than in the case of immediate pass-through.

The absence of pass-through therefore rationalises the use of strict inflation targeting in an emerging market, at least for dealing with shocks to the foreign interest rate. CPI inflation targeting becomes much closer to the policy of non-traded inflation targeting. Non-traded inflation targeting, as before, acts so as to stabilise output, by generating substantial movements in the real exchange rate. Both policy rules operate by actively employing the nominal exchange rate in order to stabilise the effective real interest rate. It is interesting to note here that while the strict 'expenditure-switching' mechanism for the exchange rate is greatly diminished, since nominal exchange rate changes no longer alter relative prices facing consumers and firms, there is still a critical role played by the exchange rate in controlling effective real interest rates. An alternative perspective is to note that while the law of one price relationship no longer holds instantaneously, the interest rate parity relationship is still an important macroeconomic linkage.

A corollary of these results is that the inflation output volatility trade-off is altered by presence the delayed pass-through. With full pass-through, we noted that the policy of stabilising non-traded goods inflation cushions the impact of an interest rate shock on GDP. But this can only be done by allowing a large initial burst of inflation, following up the exchange rate depreciation. An exchange rate peg, on the other hand, stabilises inflation, but de-stabilises GDP. But Figures 3 now shows us that both GDP and inflation can be substantially stabilised simultaneously, using either a strict inflation targeting rule, or a non-traded inflation targeting rule. Indeed, we see from the Figure that the response of inflation under an exchange rate peg is 
now, in absolute terms, as great as that under the non-traded inflation target rule. In the simulations carried out below, we will see this point more generally; delayed passthrough allows the policy maker to stabilise output without high inflation variance.

\section{Terms of Trade Shocks}

Figures 4-6 illustrate the effect of persistent negative shock to the terms of trade. In this type of model, a terms of trade shock is essentially equivalent to a negative productivity shock in the export sector: the return to investment declines. This also generates a negative wealth effect, leading to a decline in consumption. With Keynesian price rigidities, the fall in absorption leads to a fall in output in the non-traded sector, a real exchange rate depreciation, and a fall in GDP. The nontraded inflation target generates a counteracting monetary expansion, which effectively stabilises GDP, but the exchange rate peg and the strict inflation target involve a fall in output. Note that in general, the magnitude of response to a terms of trade shock is smaller than the response to an interest rate shock. There is only a very small real exchange rate depreciation and essentially no real interest rate response to the shock. As was the case for the interest rate shock, we see that the introduction of credit constraints in Figure 5 does not alter the qualitative pattern of responses to a terms of trade shock but just acts as an amplification device.

As before, incomplete pass-through in import prices significantly alters the relative performance of the alternative monetary rules: in particular, inflation targeting performs much better in terms of stabilizing output. As before, we also observe much larger real exchange rate movements for the activist monetary regimes, but much smaller inflation volatility. 


\section{Domestic Monetary Shocks}

One well-known case where a fixed exchange rate regime may be beneficial is in the presence of domestic monetary shocks. By keeping the exchange rate fixed, the monetary authority prevents these shocks from affecting aggregate demand and real domestic magnitudes. How would the presence of such shocks impact on the comparison between fixed exchange rates and inflation targeting in our analysis? The answer is that they would not impact on the comparison at all. A domestic monetary shock, for instance a shock to the interest rate rule in equation (31) above, would be eliminated equally under a strict inflation targeting policy, a nontraded goods inflation targeting policy, or a fixed exchange rate regime. By following a rule to strictly maintain either CPI inflation targeting or non-traded goods inflation, the monetary authority would prevent the interest rate shock from having any influence on the domestic economy. ${ }^{13}$

\section{Overall Regime Evaluation}

We now turn to an evaluation of the overall performance of alternative policy regimes in responding to external shocks. To obtain empirical variances, covariances and autocorrelations for the shock processes, we ran a quarterly VAR system over 1982.1 to 2000.3 for the US real interest rate and the terms of trade for the Asia region in the IMF's International Financial Statistics. The results are shown in Table 2 and indicate that there is a low correlation between shocks to the real interest rate and terms of trade. Both types of disturbance have similar variances but terms of trade shocks tend to be more persistent than interest rate shocks (autoregressive coefficients of 0.59 and 0.28 respectively). 
Table 3 shows, for each of our four scenarios, the standard deviations of key macroeconomic variables when the model is driven by the shock processes estimated in the VAR exercise. In addition, Table 3 reports a welfare comparison across regimes, where the 'loss' under a fixed exchange rate is normalized to 100 in each case. The welfare measure is calculated as a second order approximation to expected utility, following the procedure used in Woodford (1999).

In case I (no credit constraints and full pass through), the policy of non-traded goods inflation targeting delivers much lower output volatility than the other rules. It is apparent that the big difference between the rules lies in the differences in the variability of investment. Since the policy that stabilises non-traded inflation also tends to stabilise real interest rates, the volatility of investment is reduced considerably under this policy. However, at the same time, this policy generates a much higher volatility of inflation, the nominal exchange rate, and the real exchange rate than either the price stability rule or the pegged exchange rate rule. In terms of expected utility, the non-traded goods inflation targeting clearly dominates both other rules. Moreover, the price stability rule is only slightly different in terms of volatility of output, consumption investment etc, from the pegged exchange rate rule. This is not surprising given the high rate of exchange rate pass-through in this case.

Comparing cases I and II, the main impact of the introduction of credit constraints is that output, employment, and investment are significantly more volatile. But as we saw in the figures described above, the volatility of prices is unchanged. Inflation, the real exchange rate, and the nominal exchange rate have the same volatility as in case I. A key implication of case II also is that the welfare ranking of alternative monetary rules is not altered by the introduction of financing constraints.

\footnotetext{
${ }^{13}$ However, in responding to nominal shocks, the peg out-performs a 'pure' float (i.e. a fixed money
} 
Non-traded goods inflation targeting is still clearly the most preferred monetary rule. After that comes the CPI inflation targeting, and finally, a pegged exchange rate.

Case III illustrates the impact of incomplete pass-through. This has a dramatic effect on the workings of the monetary policy rules. Output volatility is lowered significantly for the two types of inflation targeting rules. Especially in the case of CPI inflation targeting, output volatility is lowered by 60 percent. Investment volatility is now lowered for both types of inflation targeting. Employment volatility changes in a slightly different way however. For the CPI inflation targeting, employment volatility falls by about 50 percent. This is because there are sticky prices in the traded goods sector now, and the CPI inflation targeting tends to stabilise a combination of the output in both traded and the non-traded sector. The non-traded goods inflation targeting policy however, leads to higher employment volatility now that in the case with full pass-through. This is intuitive, since focusing exclusively on stabilising the mark-up in non-traded goods tends to create excessive employment reallocation across sectors. Finally, real and nominal exchange rate volatility increases quite substantially when pass-through is delayed, for both types of inflation targeting.

In welfare terms, case III shows that the presence of delayed pass-through causes the rankings of policy rules to be reversed. Now the CPI inflation targeting rule does better than the non-traded goods inflation rule. Intuitively, the exclusive focus on conditions in the non-traded sector is no longer an optimal strategy for the monetary authority, since this leads to excessive movements in the real exchange rate and in resource reallocations between the traded and non-traded sectors.

stock rule) and more-restricted monetary policy strategies such as a Taylor rule that responds only to inflation and output deviations. 


\section{Conclusions}

This paper has conducted an investigation of exchange rate regimes and alternative monetary policy rules for an emerging market economy that is subject to a volatile external environment in the form of shocks to world interest rates and the terms of trade, and when the economy is constrained by external financing riskpremia associated with domestic net worth. We saw that the particular monetary policy rule being followed is as important as whether the exchange rate is fixed or flexible.

One key finding is that degree of pass-through in import prices is central in determining the stabilization properties of an inflation targeting regime. Accordingly, a high priority for (theoretical and empirical) research is to understand the determinants of the degree of pass through. Here, candidate variables include the level of trend inflation, policy credibility, policy uncertainty and the competitive structure of goods markets. A second key finding is that financial distortions amplify external shocks but have little impact on the ranking of alternative policy regimes: liability dollarization and the introduction of a financial accelerator channel does not make a fixed exchange rate a superior regime in terms of macroeconomic stabilization. 


\section{References}

Aghion, Philippe, Philippe Bacchetta, and Abhijit Banerjee (2001) "Currency Crises and Monetary Policy in an Economy with Credit Constraints," European Economic Review 47, 1121-1150.

Bernanke, Ben, Mark Gertler and Simon Gilchrist (1999), "The Financial Accelerator in a Quantitative Business Cycle Model," in John Taylor and Michael Woodford, eds, Handbook of Macroeconomics, Volume 1c, Amsterdam: North Holland, 1341-1393.

Calvo, Guillermo (1983), "Staggered Prices in a Utility Maximizing Framework," Journal of Monetary Economics 12, 383-398.

Calvo, Guillermo (1999), “On Dollarization,” mimeo, University of Maryland.

Calvo, Guillermo and Carmen Reinhart (2001), "Fear of Floating," mimeo, University of Maryland.

Cespedes, Luis Felipe, Roberto Chang, and Andres Velasco (2001a), "Balance Sheets and Exchange Rate Policy," mimeo, Harvard University.

Cespedes, Luis Felipe, Roberto Chang, and Andres Velasco (2001b), "Dollarization of Liabilities, Net Worth Effects and Optimal Monetary Policy," mimeo, Harvard University.

Chang, Roberto and Andres Velasco (1999), "Liquidity Crises in Emerging Markets: Theory and Policy," NBER Working Paper No. 7272.

Chari, V.V. Patrick J. Kehoe, and Ellen McGratten (1998), "Monetary Shocks and Real Exchange Rates in Sticky Price Models of the International Business Cycle," Federal Reserve Bank of Minneapolis Research Department Staff Report No. 223, February.

Christiano, Larry J, Martin Eichenbaum and Charles L.Evans (1997), "Sticky Price and Limited Participation Models of Money: A Comparison", European Economic Review 41, 1201-1249.

Clarida, Richard, Jordi Gali and Mark Gertler (1999), "The Science of Monetary Policy: A New Keynesian Perspective,” Journal of Economic Literature 37, 16611737.

Cook, David and Michael B. Devereux (2001), “The Macroeconomics of International Financial Panics", mimeo UBC.

De Gregorio, José, Alberto Giovannini and Holger Wolf (1994), "International Evidence on Tradables and Nontradables Inflation," European Economic Review 38, 1225-44. 
Devereux, Michael B. and Philip R. Lane (2000), "Exchange Rates and Monetary Policy in Emerging Market Economies," Hong Kong Institute for Monetary Research Working Paper No. 7/2000.

Eichengreen, Barry and Ricardo Hausmann (1999), "Exchange Rates and Financial Fragility," NBER Working Paper No. 7418.

Engel, Charles (1999), “Accounting for U.S. Real Exchange Rate Changes,” Journal of Political Economy 107, 507-38.

Gertler, Mark, Simon Gilchrist and Fabio Natalucci (2001), "External Constraints on Monetary Policy and The Financial Accelerator," mimeo, New York University.

Krugman, Paul (1999), "Balance Sheets, The Transfer Problem and Financial Crises," International Tax and Public Finance 6, 459-472.

Mankiw, N. Gregory and Lawrence Summers (1986), "Money Demand and the Effects of Fiscal Policies," Journal of Money Credit and Banking 18, 415-429.

Monacelli, Tommaso (1999), “Open Economy Rules under Imperfect Pass Through,” mimeo, Boston College.

Rogoff, Kenneth (1985) "Can International Monetary Policy Cooperation be Counterproductive?" Journal of International Economics, 18, 199-217.

Stockman, Alan and Linda Tesar (1995), “Tastes and Technology in a Two Country Model of the Business Cycle," American Economic Review 85, 168-185.

Woodford, Michael (1999), Interest and Prices, manuscript, Princeton University.

Yun, Tack (1996), "Nominal Price Rigidity, Money Supply Endogeneity, and Business Cycles,"Journal of Monetary Economics, 37, 345-370. 


\begin{tabular}{|c|c|c|}
\hline Parameter & Value & Description \\
\hline$\sigma$ & 2 & Inverse of elasticity of substitution in consumption \\
\hline$\varepsilon$ & 2 & Inverse of elasticity of substitution in real balances \\
\hline$\beta$ & 0.985 & Discount factor (quarterly real interest rate is $\frac{(1-\beta)}{\beta}$ ) \\
\hline$\rho$ & 1.0 & $\begin{array}{l}\text { Elasticity of substitution between non-traded goods and } \\
\text { import goods in consumption }\end{array}$ \\
\hline$\eta$ & 1.0 & Coefficient on labour in utility \\
\hline$\psi$ & 1.0 & Elasticity of labour supply \\
\hline$\gamma$ & 0.7 & Share of capital in export sector \\
\hline$\delta$ & 0.025 & Quarterly rate of capital depreciation (same across sectors) \\
\hline$\alpha$ & 0.3 & Share of capital in non-traded sector \\
\hline$\lambda$ & 10 & Elasticity of substitution between non-traded varieties \\
\hline$b$ & 0.55 & Share on non-traded goods in CPI \\
\hline$\kappa$ & 0.75 & Probability of non-traded firms price remaining unchanged \\
\hline$-\frac{\phi^{\prime \prime}}{\phi^{\prime}} \frac{I}{K}$ & 0.3 & $\begin{array}{l}\text { Elasticity of q with respect to } \mathrm{I} / \mathrm{K} \text { ratio (inversely related to } \\
\text { investment adjustment costs) }\end{array}$ \\
\hline$-\frac{\Psi^{\prime}}{\Psi} \frac{Z}{Q K}$ & 0.025 & Elasticity of the external finance risk premium \\
\hline$\frac{Q K}{Z}$ & 3.0 & Capital to net worth ratio (1 plus debt to net worth ratio) \\
\hline$\vartheta$ & 0.9 & Aggregate savings rate of entrepreneurs \\
\hline$\frac{W^{e} H^{e}}{Z}$ & .01 & $\begin{array}{l}\text { Share of entrepreneurial net worth coming from employment } \\
\text { income }\end{array}$ \\
\hline
\end{tabular}


Table 2: VAR Results. Asia. 1983.2-2000.3

\begin{tabular}{|l|l|l|}
\hline & Interest Rate & Terms of Trade \\
\hline Interest Rate (-1) & 0.28 & -0.12 \\
& $(2.49)$ & $(1.01)$ \\
\hline Terms of Trade (-1) & -0.09 & 0.59 \\
& $(0.99)$ & $(5.88)$ \\
\hline Constant & -0.0036 & -0.0002 \\
& $(0.24)$ & $(0.14)$ \\
\hline Adjusted R2 & 0.075 & 0.353 \\
\hline Variance(residual) & 0.00015 & 0.00017 \\
\hline Correlation(residuals) & 0.042 & \\
\hline
\end{tabular}

Note: HP-filtered quarterly data. Real interest rate is US prime lending rate minus US inflation. Terms of trade is Asian aggregate terms of trade. Source: IMF's International Financial Statistics CD-ROM. 


\section{Table 3 Standard Deviations}

\begin{tabular}{|c|c|c|c|c|c|c|c|c|c|}
\hline I: NCC PT & Output & Cons & Investment & Real ER & Inflation & Nominal ER & Hours & $\mathrm{MCN}$ & "Loss" \\
\hline NT & 0.14 & 0.59 & 3.9 & 1.22 & 1.76 & 2.43 & 0.51 & 0 & 37.72 \\
\hline Pstab & 0.99 & 0.93 & 6.29 & 0.45 & 0 & 0.51 & 0.7 & 3.61 & 83.74 \\
\hline Peg & 1.11 & 0.98 & 6.65 & 0.34 & 0.3 & 0 & 0.82 & 4.08 & 100 \\
\hline
\end{tabular}

II: CC PT Output Consumption Investment Real ER Inflation Nominal ER Hours MCN "Loss"

\begin{tabular}{|c|c|c|c|c|c|c|c|c|c|}
\hline NT & 0.3 & 0.5 & 4.55 & 1.21 & 1.76 & 2.42 & 0.54 & 0 & 28.70 \\
\hline Pstab & 1.12 & 0.81 & 7.02 & 0.46 & 0 & 0.51 & 0.96 & 3.62 & 83.23 \\
\hline Peg & 1.25 & 0.85 & 7.42 & 0.35 & 0.3 & 0 & 1.09 & 4.09 & 100 \\
\hline III: NCC DPT & Output & Consu & on Investment & Real ER & Inflation & Nominal ER & Hours & MCN & "Loss" \\
\hline NT & 0.1 & 0.33 & 1.74 & 2.66 & 0.25 & 2.88 & 0.77 & 0 & 41.51 \\
\hline Pstab & 0.4 & 0.54 & 3.42 & 1.69 & 0 & 1.71 & 0.38 & 1.5 & 27.50 \\
\hline Peg & 1.1 & 0.97 & 6.62 & 0.35 & 0.3 & 0 & 0.81 & 4.06 & 100 \\
\hline
\end{tabular}

Note: NCC PT; CC PT; NCC DPT; CC DPT refer to "no credit constraints / full pass through"; "credit constraints / full pass through"; "no credit constraints / incomplete pass through"; and "credit constraints / incomplete pass through" respectively. NT refers to monetary rule of targeting real marginal cost (MCN) in the nontraded sector; Pstab to inflation targeting; and Peg to fixing the nominal exchange rate. 
Figure 1: Interest rate shock, benchmark model
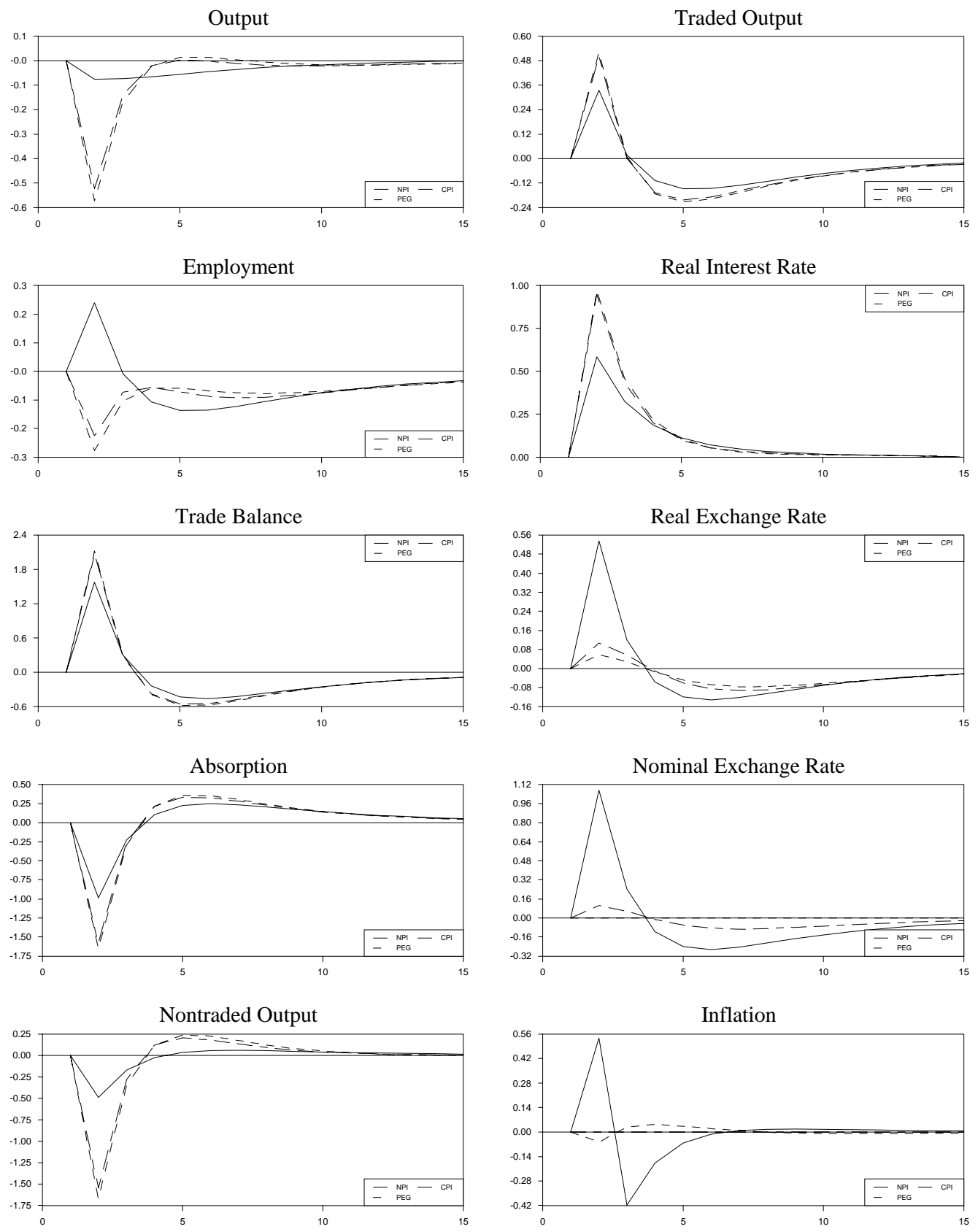
Figure 2: Interest rate shock, finance constraints
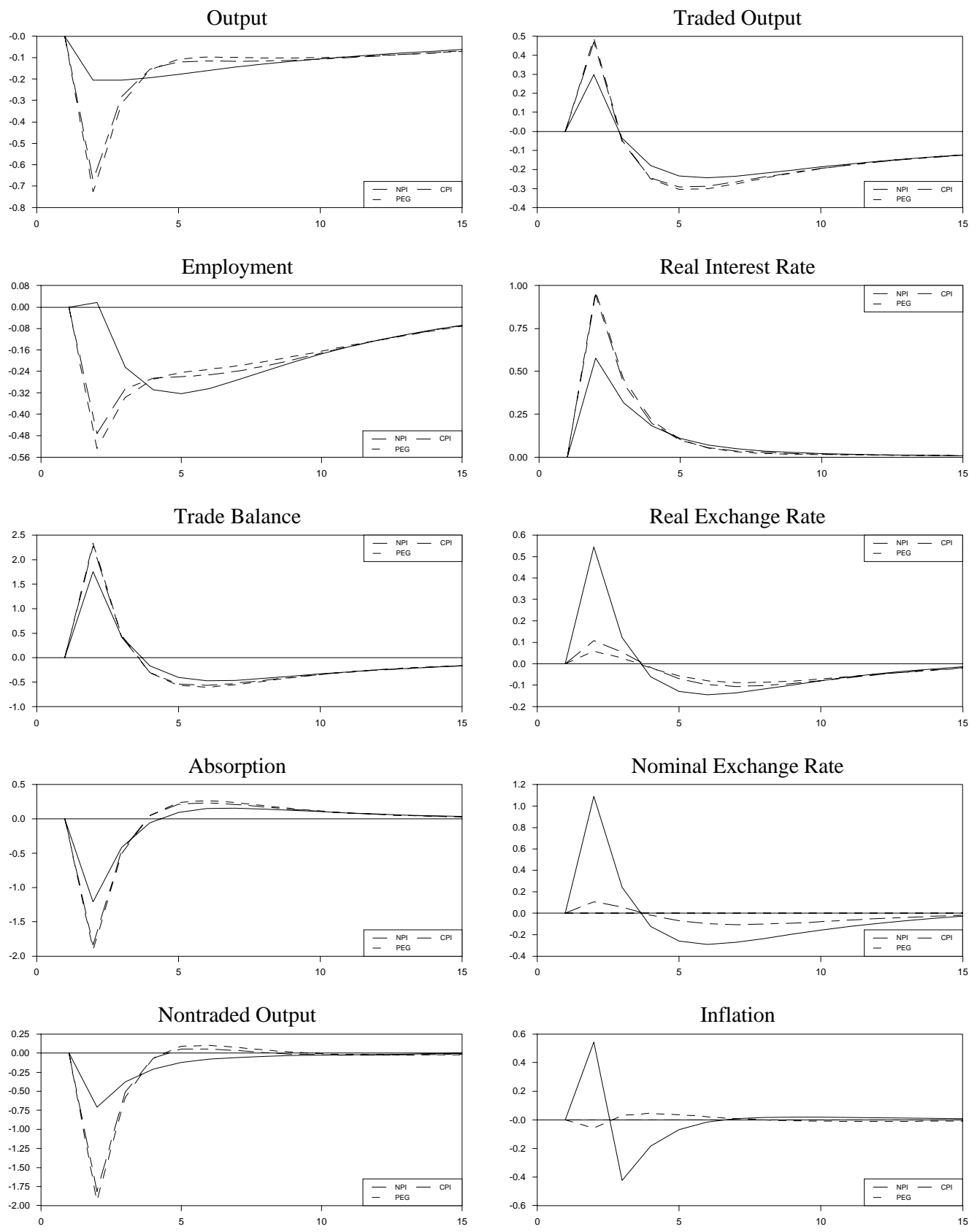
Figure 3: Interest rate shock, delayed pass-through
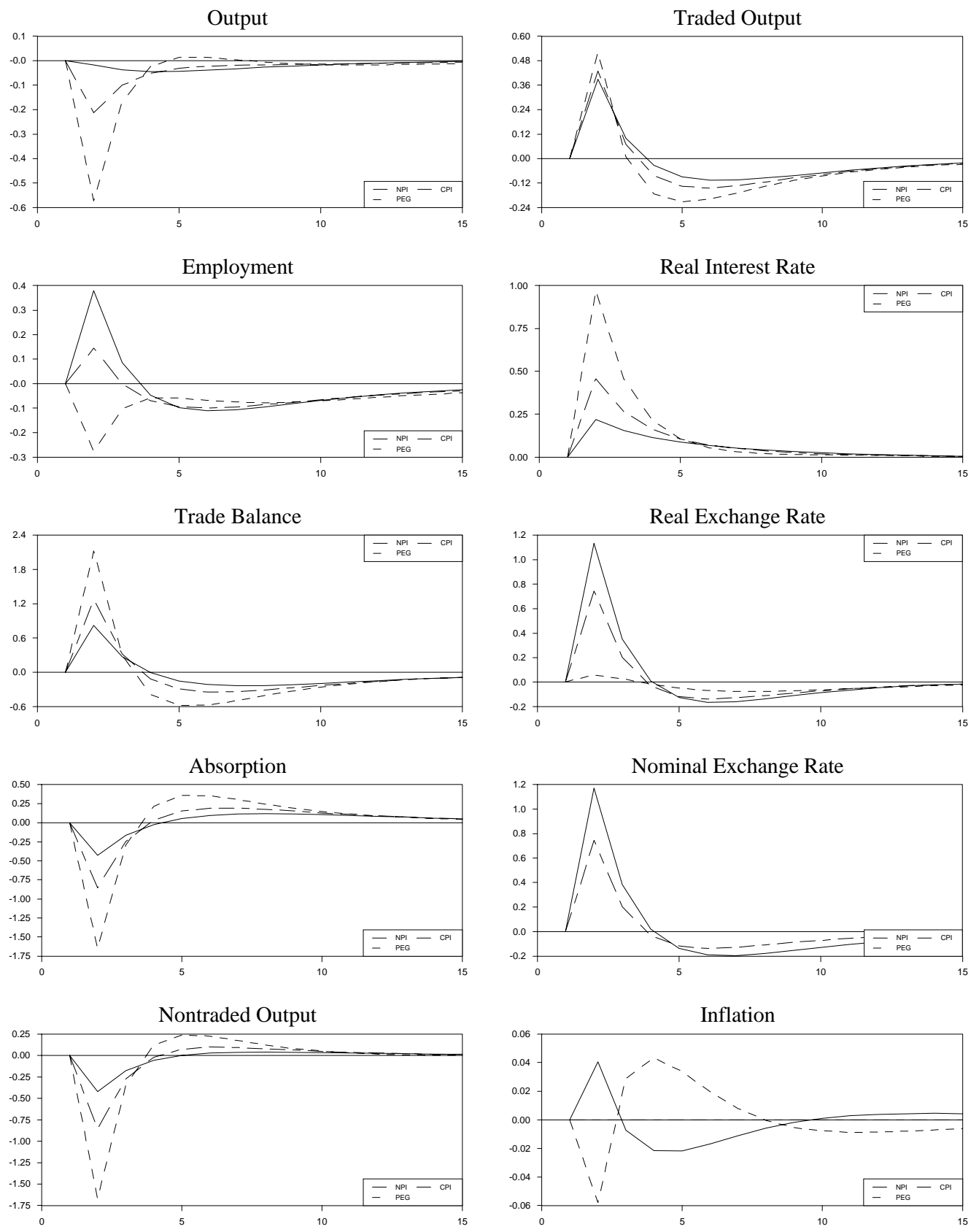
Figure 4: Terms of trade shock, benchmark model
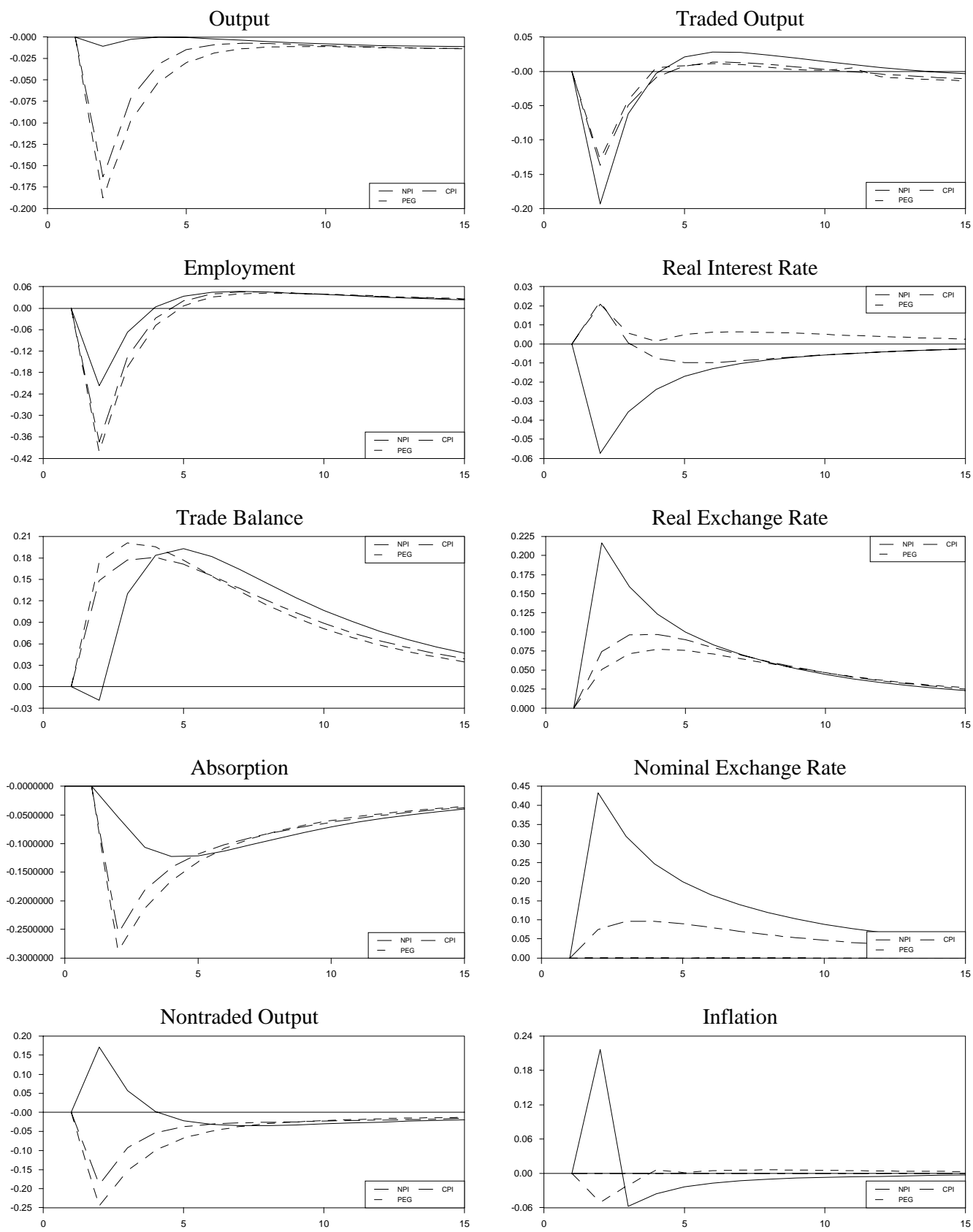
Figure 5: Terms of trade shock, finance constraints
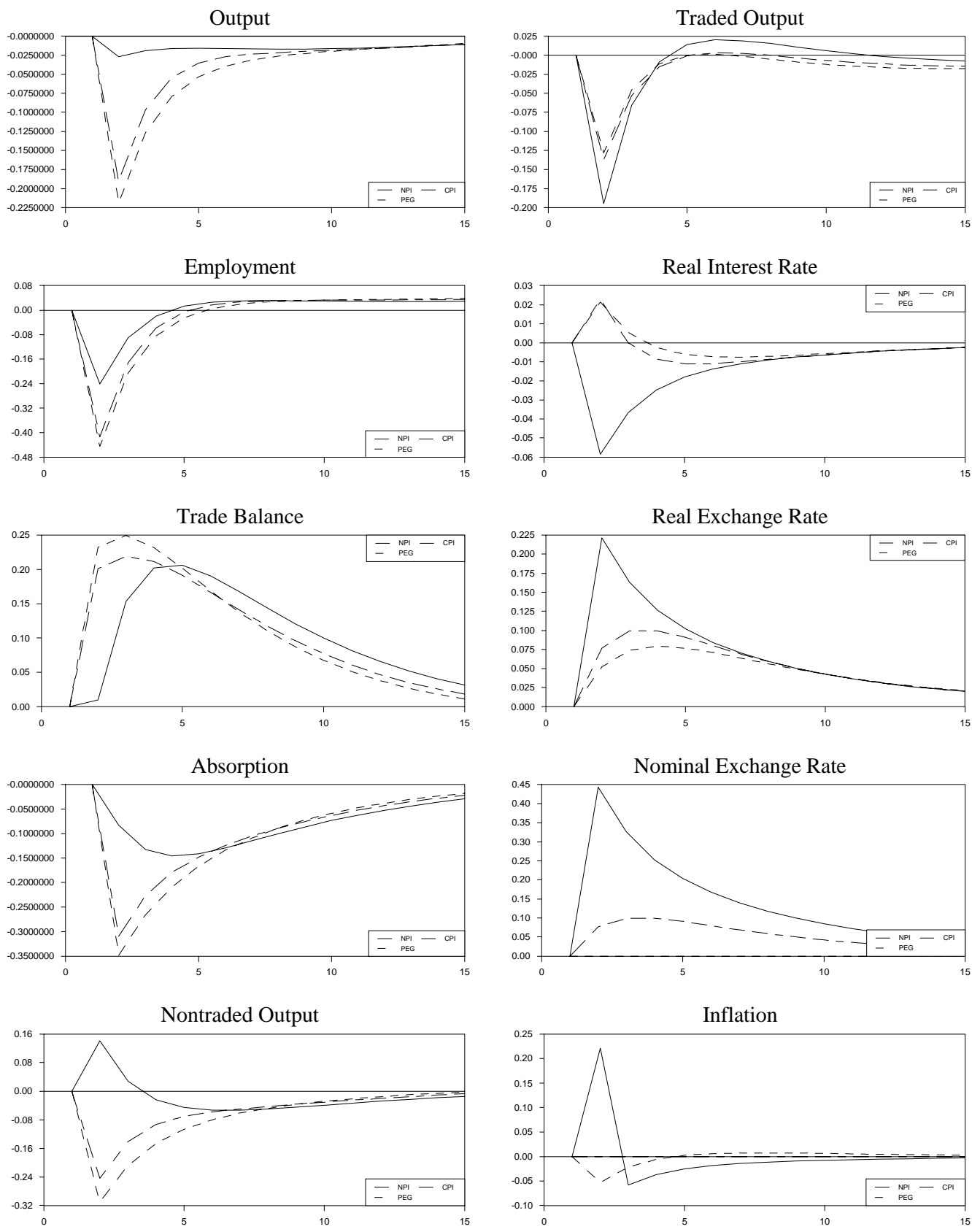
Figure 6: Terms of trade shock, delayed pass-through
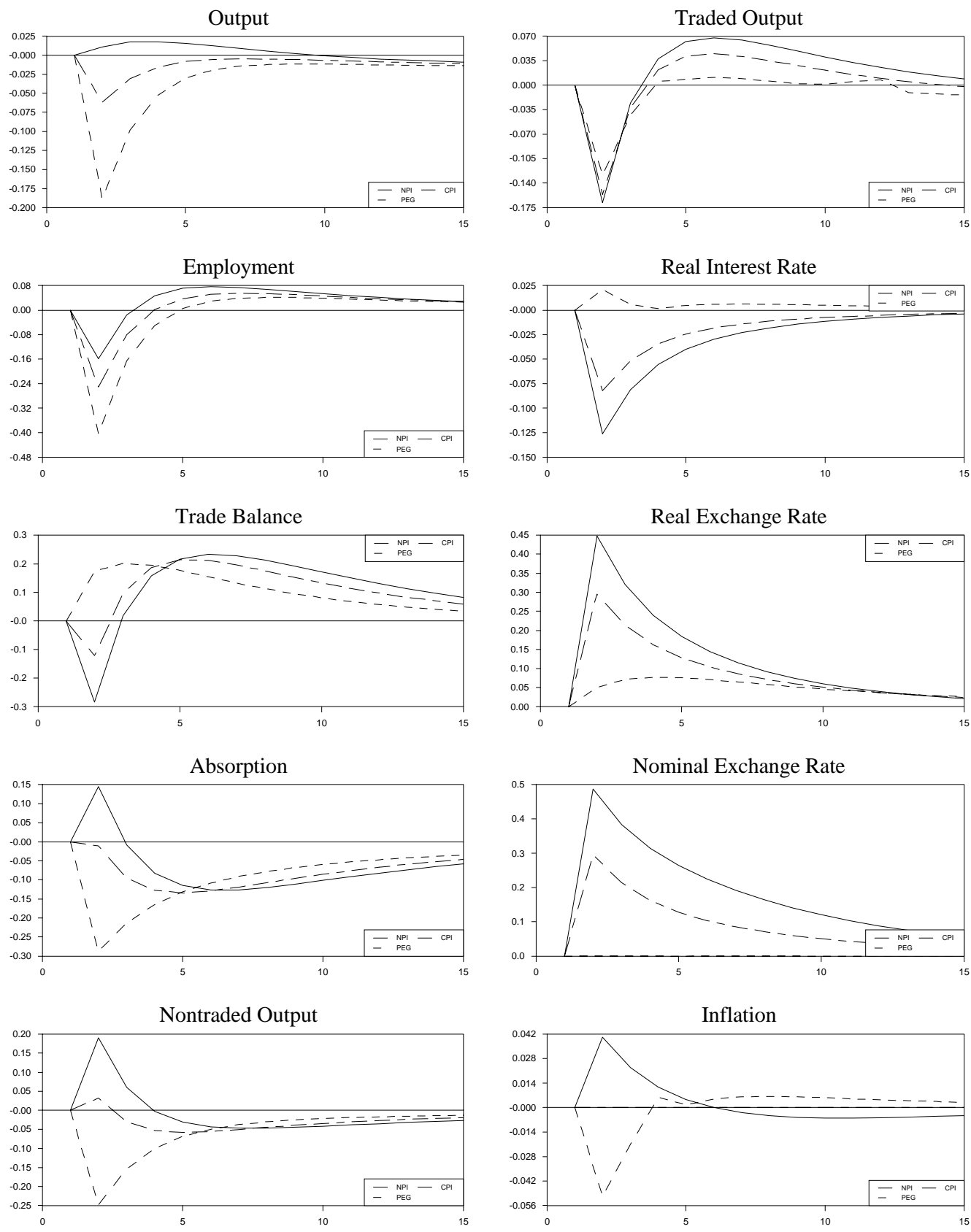